\title{
In Vitro Studies on Tropical Orchid, Vanilla planifolia using different Concentration of Growth Regulators
}

\author{
Srinivasan Kameswaran ${ }^{1}$, Karupan Perumal ${ }^{2}$ \\ ${ }^{1}$ Department of Botany, Vikarama Simhapuri University PG Centre, Kavali-524201, Andhra Pradesh, India \\ ${ }^{2}$ Shri AMM Murugappa Chettiar Research Centre, Taramani, Chennai-600113. Tamil Nadu, India
}

\begin{abstract}
Natural vanilla flavours are presently in high demand in food industry and alternate routes of production of these through secondary metabolic pathways using plant cell and tissue culture could constitute the best technology for immediate future. In vitro production of natural vanillin could be achieved through two different methods. In the first, organised root tissue formed from the explants produces vanilla flavour compounds in precursor feeding experiments. The flavour production proceeds through the phenylpropanoid pathway in which the organised root tissues function as biocatalysts. Ferulic acid has proved to be the best source for the flavour compounds. In the second method, the callus maintained in Murashige and Skoog (MS) medium containing a specific combination of growth regulators is used in precursor feeding experiments as before for production of flavour.
\end{abstract}

Keywords: nodal explants, organised root tissues, vanilla flavours, Vanilla planifolia Andr.

\section{Introduction}

Vanilla flavour (Vanilla planifolia Andr.) is an important food additive and the present worldwide consumption of vanillin is estimated to be 12,000 tonnes. Approximately 50 tonnes are in the form of natural vanillin extracted from beans of Vanilla planifolia, with synthetic vanillin providing the remainder from petrochemical and wood pulping industry. The natural vanillin costs US $\$ 4,000 / \mathrm{kg}$ depending on quality, compared with US \$15/kg for synthetic vanillin (Lomascolo et al.,.. 1999). The synthetic vanillin currently in widespread use as in the process of losing demand as it contains only a single compound made from plant lignin (Nabard, 1998). Strong market demand for natural and environmentally friendly products has spawned efforts to produce vanillins by natural means. But the natural vanilla flavour is far superior due to the presence of more than 250 compounds (Riley and Kleyn, 1989; Adedeji et al.,., 1993). The traditional method of production of natural vanillin is cumbersome as it involves cultivation of plants in restricted climatic regions, hand (manual) pollination with limited success and the tedious processes for curing and extraction of products from the pods. Again, as flowering is seasonal the production of natural vanillin is also seasonal. The tissue culture method envisaged here could be used throughout year in laboratories / factories and for commercial production.

Plant tissue cultures are potentially valuable for studying the biosynthesis of secondary metabolites. In view of the current consumer demands for natural foods and plant-derived medications, in vitro production of valuable secondary products has become an industrially promising venture. The production of flavour compounds with cultured plant cells is based upon their unique biochemical and genetic capacity and the totipotency of plant cells (Schleiden, 1838; Schwann, 1839). Thus, every cell of the Vanilla plant contains the genetic information necessary to produce the numerous biochemical components (or their precursors) that constitute natural vanilla flavour. The potential advantages of plant tissue culture systems include; independence from environmental factors, geographical indications, uniformity and controlled production in response to demand.

Biosynthesis of natural vanillin and other related compounds follows the phenylpropanoid pathway (Funk and Brodelius, 1994, Knorr et al., 1993). All the enzyme systems required for the biosynthesis of natural flavours from precursor are present in cultured cells. These cells could thus function as biocatalysts if cultures are provided with the precursors. Since the natural vanillin flavour contains over 250 organoleptic compounds, the ideal precursors for their synthesis through phenylpropanoid pathway appear to be phenylalanine - cinnamic acid - coumaric acid - caffeic acid - isoferulic acid - 3,4-dimethoxycinnamic acid - 3,4dimethoxybenzoic acid - vanillic acid (after Funk and Brodelius, 1992).

Plant cell cultures of V.planifolia and other species have been initiated from cells, tissues and plant organs such as leaves and stems (Davidonis and Knoor 1991, Zerihum et al.,., 2009, Geetha and Shetty 2000, Zuraod et al.,., 2013, Foong Jing et al., 2014, Renuga and Saravana Kumar 2014, Jadid et al., 2015, Nurcahyani et al., 2015, Vijaykumar Biradar et al., 2016), growing plant shoot tip, roots and seeds (Knuth and Sahai, 1991) or green capsules (Funk and Brodelius 1990; Knuth and Sahai, 1991).

The effect of several plant hormones and their combinations on flavour production and composition of vanilla components are examined by Knuth and Sahai (1991). The Influence of growth regulators on cell growth and formation of phenolic substances has also been explored by Funk and Brodelius (1990). Funk and Brodelius (1992) have also studied the activation effect of kinetin on some enzymes involved in the phenylpropanoid pathway. The possibility of a bioprocess for the production of natural vanillin from a ferulic acid precursor with aerial roots as the biocatalysts 


\section{International Journal of Science and Research (IJSR) \\ ISSN (Online): 2319-7064}

Index Copernicus Value (2015): 78.96 | Impact Factor (2015): 6.391

and charcoal product reservoir has been carried out by West Cott et al (1994). However in our experiment, the in vitro protocol was developed to mass culture vegetative tissues of V.planifolia for production of flavour compounds.

\section{Material and Methods}

\section{Cultivation of cuttings}

Cuttings of V.planifolia raised in pots, which contains soil and farmyard manure (FYM) 1:1 ratio (Rosman, R; TasmaIM 1998) in a partially natural shaded place in our centre from where the explants are collected. Previously mother cuttings were obtained from M/s. Parry Agro Industries Ltd., Candura - Sheikalmudi Estate, Coimbatore District, Tamil Nadu.

\section{Explants preparation}

Shoot tips and young nodal segments with petioles were excised approximately $2 \mathrm{~cm}$ from mature healthy vines. These explants were soaked in liquid detergents (Tween 20) for $3 \mathrm{~min}$. and then rinsed in running tap water for $10 \mathrm{~min}$. The cleaned explants were surface sterilized with mercuric chloride $0.1 \%(\mathrm{~W} / \mathrm{V})$ for 8 minutes followed by 10 rinses with 2 minutes intervals in sterile distilled water aseptically. Surface sterilized explants were trimmed out at their cut ends.

\section{Media and primary culture initiation}

Murashige and Skoog (1962) (MS) medium supplemented with various plant growth hormones (HiMedia, Mumbai, India) in the combination of Naphthaleneaectic acid (NAA) 2-6 mg/l with 2,4-dichlorophenoxy acetic acid (2,4-D) 0.5$1 \mathrm{mg} / \mathrm{l}$ and 6-benzyladenine (BA) 1-2 $\mathrm{mg} / \mathrm{l}$ were used for primary culture initiation. The $\mathrm{pH}$ of the MS medium with $3 \%$ sucrose was adjusted $5.6 \pm .2$ prior to sterilisation and gelled with $0.9 \%$ (W/V) agar (HiMedia, Mumbai, India) and sterilized for 20 minutes under $1.05 \mathrm{~kg} / \mathrm{cm}^{2}$ pressure at $121^{\circ} \mathrm{C}$. The cultures were incubated under cool fluorescent lights with 1500-2000 Lux for $16 \mathrm{hrs}$ at a temperature of $25 \pm 2$ and $70 \pm 10$ relative humidity. Axillary bud with base of petiole containing nodes and shoot tips were inoculated vertically by inserting around $5 \mathrm{~mm}$ of the lower end in to medium aseptically. Each treatment had ten replicates and data were documented after 40 days of culture.

\section{Organised Root Tissues (ORT) and callus establishment}

MS media supplemented with NAA $2.5 \mathrm{mg} / 1$ and BA 1.0 $\mathrm{mg} / \mathrm{l}$ were used for organised root tissue formation from nodal explants, after four weeks that the cultures were subcultured in the same medium with increased concentration of NAA up to $8.0 \mathrm{mg} / \mathrm{l}$ and BA $3.0 \mathrm{mg} / \mathrm{l}$.

Callus cultures were well established from the base of shoot bud and young leaf petiole in MS media supplemented with low concentration of NAA and BA. Nature of callus was pale yellow in colour. The callus was subcultured for further proliferation and biomass production by altering the concentration and combination of PGRs under same physical parameters.

\section{Extraction and analysis of flavour compound}

Organised root biomass were transferred from specific hormonal media (Table 1) to the hormone free medium and treated with ferulic acid as precursor, after incubation for 72 hrs extracted of flavour compounds according to the method followed by Westcott et al.,., 1994. Similar experiments were done with callus tissues.

The various explants were also tried for callus initiation on the MS media containing 2,4-D and other auxins. In vitro callus cultures $1 \mathrm{~g}$ were harvested extracted using $70 \%$ ethanol (Kunth and Shai, 1989) in a soxhlet for 48 hours. The extract was dissolved in HPLC grade water and remaining residue was dissolved in of HPLC grade methanol separately. These extracts were filtered through sartorius RC-membrane syringe filter $(0.20 \mu \mathrm{m})$ and $10 \mu \mathrm{l}$ was injected. Chromatography was carried out using Shimadzu HPLC with auto sampler and standard C18 column $(25 \mathrm{~cm} \mathrm{x}$ $4.6 \mathrm{~mm}$ ). The mobile phase consisting of methanol: acidified water was used in ratio of 1:9. Acidified water was prepared by mixing HPLC grade glacial acetic acid and water in the ratio of 1: 80 . Degassing was performed under vacuum. Flow rate was $2.5 \mathrm{ml} / \mathrm{min}$; back pressures 250 psi and compounds read at $254 \mathrm{~nm}$ in an UV detector. The total run time was $30 \mathrm{~min}$, but it is preferable if the time is extended to $40 \mathrm{~min}$. The identification and quantification of compounds were achieved by direct comparison with authentic standard (AOAC Official method 990.25).

\section{Results and Discussion}

\section{Primary culture establishment}

Initially the primary culture establishment was from young nodal explants of V.planifolia cultured in 3\% sucrose containing basal MS medium supplemented with different PGRs at various concentrations in different proportion. The medium supplemented with NAA upto $2.0 \mathrm{mg} / \mathrm{l}$ and BA upto $1.0 \mathrm{mg} / 1$ showed that only axillary bud was developed into a single plantlet without forming any remarkable initiation. Primary culture could be established in medium supplemented with increased level of NAA ( $>2.0 \mathrm{mg} / \mathrm{l})$ and BA 1.0 to $2.0 \mathrm{mg} / \mathrm{l}$ (Fig1). The organised yellow tissue was formed at base of axillary bud as well as at cut base of young nodal segment (Table 1). There was a clear indication that the NAA and BA combination resulted in formation of organised tissues from various young explants such as axillary bud, leaf and shoot tips, but not with rootlet. When culture of mature nodal explant was grown in media supplemented with NAA $2.5 \mathrm{mg} / \mathrm{l}$ and BA $2.0 \mathrm{mg} / \mathrm{l}$ multiple shoots were observed (Fig 1e), but with the same combination the young shoot tips respond to form organised tissues at cut base (Fig 1a). The type of explants also plays a vital role in explant culture morphology. 


\section{International Journal of Science and Research (IJSR) \\ ISSN (Online): 2319-7064}

Index Copernicus Value (2015): 78.96 | Impact Factor (2015): 6.391

Table 1: Effect of PGRs on organised tissue development in V. palnifolia (Data were reordered after 40 days in culture)

\begin{tabular}{|c|c|c|c|}
\hline No. & $\begin{array}{c}\text { MS media with } \\
\text { PGRs mg/l }\end{array}$ & $\begin{array}{c}\text { Explants /Organised Root Tissue (ORT) } \\
\text { culture }\end{array}$ & Tissue proliferation \\
\hline A & NAA 2.5 + BA 2.0 & Matured nodes & Multiple shoot buds \\
\hline B & NAA 2.5 + BA 2.0 & Young shoot tip & Yellow coloured organised tissues at cut end \\
\hline C & NAA 2.5+ 2,4-D 1.0+ BA 2.0 & Axillary bud / young leaf base & Yellow coloured organised tissues at cut end \\
\hline D & NAA 3.0+ BA 1.0 & Axillary bud & Yellow coloured organised tissues at base of bud \\
\hline E & NAA 4.0+ BA 2.0 & Nodal explant/ORT & ORT with pale yellowish green colour projections \\
\hline F & NAA 5.0+ BA 2.0 & Nodal explant/ORT & Globular ORT with root hairs \\
\hline G & NAA 6.0+ BA 2.0 & Nodal explant/ORT & Globular green fused ORT \\
\hline H & NAA 6.5+ BA 2.0 & Nodal explant/ORT & Globular ORT with numerous root hairs \\
\hline
\end{tabular}

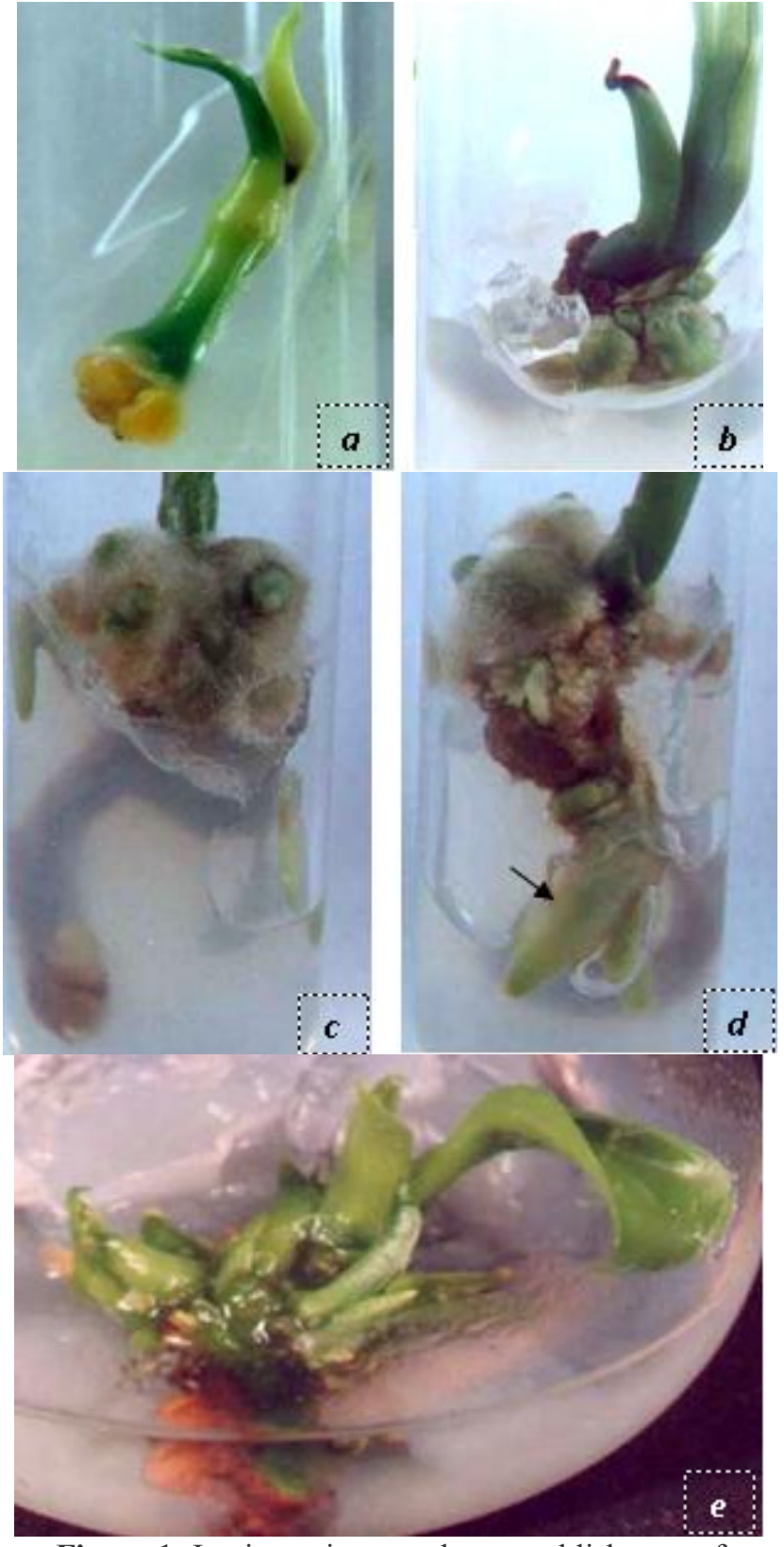

Figure 1: In vitro primary culture establishment of

V.planifolia on MS medium with various PGRs. a-d organised tissue formations from various explants. a-Young shoot tip on medium with NAA $2.5 \mathrm{mg} / \mathrm{l}$ and BA $2.0 \mathrm{mg} / \mathrm{l}$. b-d Nodal explant b on medium with NAA $4.0 \mathrm{mg} / \mathrm{l}$ and BA2.0 mg/l. c and d on medium with NAA $5.0 \mathrm{mg} / \mathrm{l}$ and
BA2.0 mg/l (observe the development of root let in $\mathbf{d}$ ) e Multiple shoots development from mature node on medium with NAA $2.5 \mathrm{mg} / \mathrm{l}$ and BA $2.0 \mathrm{mg} / \mathrm{l}$.

Organised Root Tissues (ORT) and Callus establishment

The organised yellow tissue was developed into organised root tissue when subcultured in increased level of NAA (4$6.5 \mathrm{mg} / \mathrm{l})$ and BA (2.0 mg/l) containing MS media (Fig. $2 \mathrm{a}-$ d) and (Table E-H). The maximum biomass could be harvested from these cultures (Fig. 3). In the media containing less than $4 \mathrm{mg} / \mathrm{l} \mathrm{NAA}$ does not develop into organised root tissue.

The observation also revealed that the nodal explant of axillary bud developed into plantlet. In this plantlet multiple buds developed around its nodes. Those nodal segments were subcultured in same combination of NAA $2.0 \mathrm{mg} / \mathrm{l}$ and BA $2.0 \mathrm{mg} / \mathrm{l}$ for establishment of multiple buds. Each bud around $1 \mathrm{~cm}$ length was separated and subcultured after 21 days in different combinations. Callus was formed at the base of shoot bud in NAA $1.0 \mathrm{mg} / \mathrm{l}$ and BA $1.5 \mathrm{mg} / \mathrm{l}$ in MS medium. (Fig 2f)

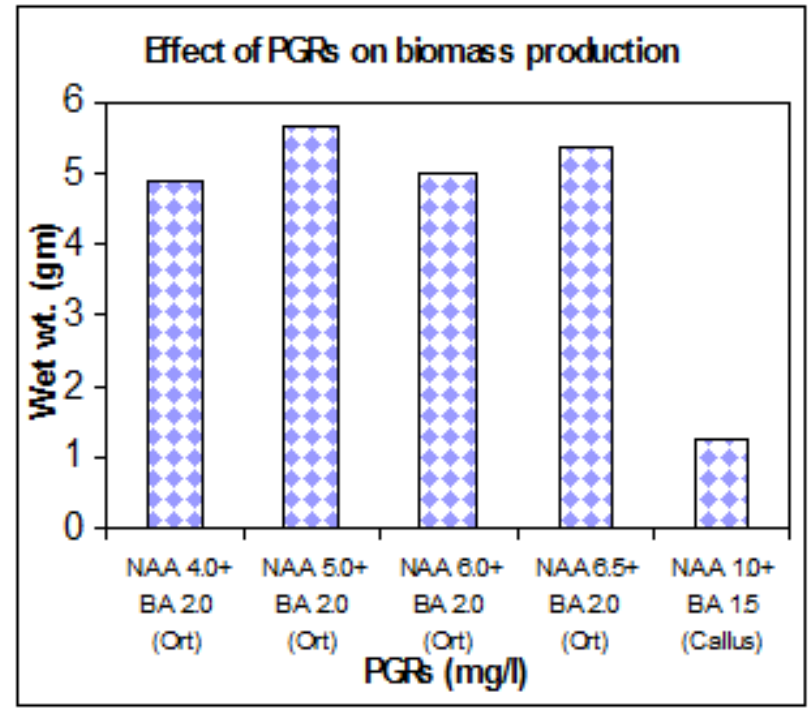

Figure 3: Data were reordered after 40 days in culture

\section{Volume 6 Issue 1, January 2017 www.ijsr.net}




\section{International Journal of Science and Research (IJSR) ISSN (Online): 2319-7064}
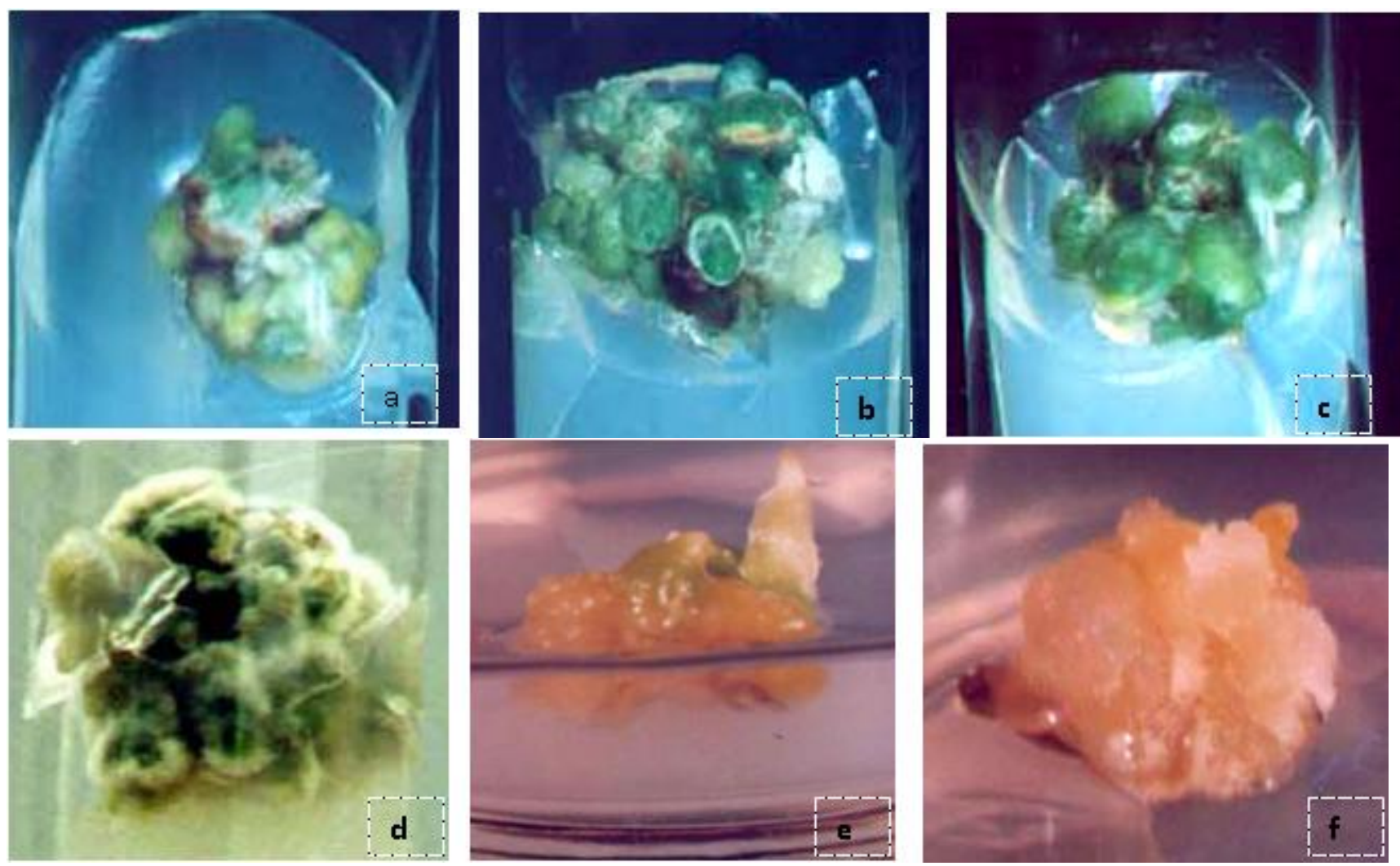

Figure 2: Establishment organised root tissue (ORT) and callus of V.planifolia on MS medium with various PGRs. a-d Organised root tissue formations. a-Pale yellowish green ORT on medium with NAA $4.0 \mathrm{mg} / \mathrm{l}$ and BA $2.0 \mathrm{mg} / 1$. b medium with NAA $5.0 \mathrm{mg} / \mathrm{l}$ and BA2.0 mg/l. c medium with NAA $6.0 \mathrm{mg} / \mathrm{l}$ and BA2.0 mg/l d ORT with numerous hairs on medium with NAA $6.5 \mathrm{mg} / \mathrm{l}$ and BA2.0 mg/l e - shoots development on medium with NAA $2.0 \mathrm{mg} / \mathrm{l}$ and BA $2.0 \mathrm{mg} / \mathrm{l}$. f callus development on medium with NAA $1.0 \mathrm{mg} / \mathrm{l}$ and BA $1.5 \mathrm{mg} / \mathrm{l}$.

Vanilla plant tissue provides an excellent source for the production of vanillin and other related compounds. Organised vanilla tissue very rarely forms a callus. This is not surprising because vanilla is a monocotyledon and an orchid, a plant group with little tendency towards dedifferentiation in tissue cultures. In our experiments we could develop callus but biomass yield was very low, only $20 \%$ of the root biomass (Fig 2 -f). Hence option for organised root tissue biomass development is more apt since the root contains highest concentration of vanillin compared to other somatic tissues $(200 \mu \mathrm{g} / \mathrm{g}$ dry wt.). The root tissue also is amenable to precursor treatment as it acts as biocatalyst. The addition of ferulic acid increases the vanillin concentration to $489 \mu \mathrm{g} / \mathrm{g}$ after 72 -hrs incubation (Westcott et al.,.., 1994). The flavour production proceeds through the phenylpropanoid pathway in which the organised root tissues function as biocatalysts. In our experiments the yield of vanillin from organised root tissue was more than $30 \%$ to that present in vanilla beans. The results are of considerable significance for the development of an efficient biocatalyst process for continuous production of the vanilla flavour from cultured vegetative root tissue. This holds immense potential for the commercial production of natural vanillins using precursors which can be obtained residues from sugar and paper-mill industries in scale up studies. This has dual benefits by using wastes the pollution low is reduced and cheap substrates are used to produce highly valuable flavours.

\section{Acknowledgements}

The authors thanks to Shri AMM Murugappa Chettiar Research Centre, Tharamani, Chennai 600113 (TN) India, for providing a research fellowship and financial assistance, also thanks to Dr. T. M. Vatsala for her valuable suggestions during this study.

\section{References}

[1] Ab Rahman Zuraid, Kamarulzaman, Hassan Fatin Liyana, Izzati Othman Ayu Nazreena, Wan Sembok Wan Zaliha, Che Mohd, Zain Che Radziah, Zainal Zamri and Subramniam Sreeramanan. 2013. A simple and efficient protocol for the mass propagation of Vanilla planifolia. American Journal of Plant Sciences. 4, 1685-1692.

[2] Adedeji, J, Hartman T G and Ho C-T 1993. Flavour characterization of different variants of vanilla beans. Perfumer and Flowerist 18: 25-33.

[3] Cheetham P S J., 1993. The use of biotransformations for the production of flavours and fragrances. TIBTECH $11478-488$.

[4] Davidonis G and Knorr D., 1991. Callus formation and shoot regeneration in Vanilla planifolia. Food Biotechnology 5 (1) $59-66$.

[5] Efficient in vitro multiplication protocol for Vanilla planifolia using nodal explants in Ethiopa. African Journal of Biotechnology. Vol.8 (24); pp.6817-6821. 


\section{International Journal of Science and Research (IJSR) \\ ISSN (Online): 2319-7064 \\ Index Copernicus Value (2015): 78.96 | Impact Factor (2015): 6.391}

[6] Funk C and Brodelius P.E, 1990. Influence of growth regulators and an elicitor on phenylpropanoid metabolism in suspension cultures. Phytochem. 29 (3) 845-848.

[7] Funk C and Brodelius P.E, 1992. Phenylpropanoid metabolism in suspension cultures of Vanilla planifolia Andrew IV Induction of Vanillic acid formation. Plant Physiology 99, 256-262.

[8] Geetha S. and Sudheer A. Shetty, 2000. In vitro propagation of Vanilla planifolia, a trophical orchid. Current Science. Vol.74, No.6.

[9] Goh Foong Jing, Wan Nur Aqilahbinti Wan AB Razak, Zuraida Ab Rahman and Sreeramanan Subramanian. 2014. The effect of thin cell layer system in Vanilla planifolia in vitro culture. Current Botany. 5: 22-25.

[10] Hagedorn, S., and B. Kaphammer, 1994. Microbial biocatalysts in the generation of flavour and fragrance chemicals. Annu. Rev. Microbial. 48: 778-800.

[11] Knuth M E and Sahai O P., 1991. Flavour composition and method. United States Patent No 5. 057. 424.

[12]Lomascolo, A., Stentelaire, C., Asther, M., and Meessenet, L.L., 1999. Besidiomycetes as new biotechnological tools to generate natural aromatics flavour for the food industry. TIBTECH, July Vol.-17.

[13] Narbad, A., 1998. Take a pinch of bacteria... New Scientist, Vol., 23 May 1998.

[14] Nurcahyani, E., Suharyanto, E., Hadisutrisno, B. and Sumardi, I. 2015. In vitro selection of fusaric acid of Vanilla planifolia plantlets for obtaining a cultivar, which resistant to Fusarium oxysporum f. sp. Vanilla. ISSN 2413-0877 Volume 2. 617-620.

[15] Nurul Jadid, Tutik Nurhidayati and Priyono. 2015. In vitro clonal propagation of Vanilla planifolia Andrews using microshoot-derived node explants. J. Appl. Environ. Biol. Sci. 5 (6): 105-110.

[16] Renuga G. and Saravana Kumar S.N. 2014. Induction of Vanillin related compounds from nodal explants of Vanilla planifolia using BAP and Kinetin. Asian Journal of Plant Science and Research. 4 (1): 53-61.

[17] Riley K A and Kleyn D H 1989. Fundamental principal of vanilla/vanilla extract processing and methods of detecting adultration in vanilla extracts. Food Tech. 43(10): 64-77.

[18] Rosman R., Tasma I M 1988. The effect of farmyard mannure rate on the growth of vanilla cuttings. Pemberitaan-Penelitian-Tanaman-Industri. 13: 3-4, 6568, 4ref.

[19] Schleiden, M J., 1838. Beitrage zur Phytogenesis. Muller Arch. Anat. Physiol.: 137 - 176.

[20] Schwann, T. 1839 Mikroskopische Unter suchgen under die Ubereinstimung inder Strukur und in dem Wachstum der Thiere und Planzen. Nr. 176, 40(4): 198200.

[21] Vijaykumar Biradar, Ashashree Inamdar, Aswini Shamse and M.S. Patil. 2016. In vitro studies on the Influence of different concentration of growth regulators on Economically important Orchid, Vanilla planifolia. Int. J. Curr. Microbiol. App. Sci. 5(9): 311323.

[22] Webster. T.M., 1995. New perspectives on vanilla. Cereal Foods World. 40 (4): 198-200.

[23] Westcott, R.J., Cheetham, P.S.J. and Barraclough, A.J., 1994. Use of organised viable vanilla plant aerial roots for the production of natural vanillin. Phytochem. 35(1): 135-138.

[24]Zerihum Abebe, Ayelign Mengesha, Alemayehu Teressa and Wondyfraw Tefera. 2009. 